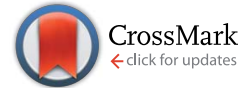

Cite this: Chem. Sci., 2016, 7, 5108

\title{
Tuneable mechanical and dynamical properties in the ferroelectric perovskite solid solution $\left[\mathrm{NH}_{3} \mathrm{NH}_{2}\right]_{1-x}\left[\mathrm{NH}_{3} \mathrm{OH}\right]_{x} \mathrm{Zn}(\mathrm{HCOO})_{3} \uparrow$
}

\author{
Gregor Kieslich, $\star^{* a}$ Shohei Kumagai,,$^{\text {abc }}$ Alexander C. Forse, ${ }^{d}$ Shijing Sun, ${ }^{a}$ \\ Sebastian Henke, ${ }^{\text {ae }}$ Masahiro Yamashita, ${ }^{\text {bc }}$ Clare P. Grey ${ }^{d}$ and Anthony K. Cheetham*a
}

We report how mechanical and dynamical properties in formate-based perovskites can be manipulated by the preparation of an A-site solid-solution. In the series $\left[\mathrm{NH}_{3} \mathrm{NH}_{2}\right]_{1-x}\left[\mathrm{NH}_{3} \mathrm{OH}\right]_{x} \mathrm{Zn}(\mathrm{HCOO})_{3}$ with $x_{\max }=0.48$, the substitution of $\left[\mathrm{NH}_{3} \mathrm{NH}_{2}\right]^{+}$by $\left[\mathrm{NH}_{3} \mathrm{OH}\right]^{+}$is accompanied by a series of complex changes in crystal chemistry which are analysed using PXRD, SCXRD, ${ }^{1} \mathrm{H}$ solid state NMR, DSC and nanoindentation. NMR shows increased motion of $\left[\mathrm{NH}_{3} \mathrm{NH}_{2}\right]^{+}$in $\left[\mathrm{NH}_{3} \mathrm{NH}_{2}\right]_{0.52}\left[\mathrm{NH}_{3} \mathrm{OH}\right]_{0.48} \mathrm{Zn}(\mathrm{HCOO})_{3}$, which results in a shift of the ferroelectric-to-paraelectric phase transition temperature from $T_{\mathrm{c}}=352 \mathrm{~K}(x=0)$ to $T_{\mathrm{c}}=324 \mathrm{~K}$ $(x=0.48)$. Additionally, the loss of hydrogen bonds directly influences the mechanical response of the framework; the elastic moduli and hardnesses decrease by around $25 \%$ from $E_{110}=24.6 \mathrm{GPa}$ and $H_{110}=$ $1.25 \mathrm{GPa}$ for $x=0$, to $E_{110}=19.0 \mathrm{GPa}$ and $H_{110}=0.97 \mathrm{GPa}$ for $x=0.48$. Our results give an in-depth insight into the crystal chemistry of $\mathrm{ABX}_{3}$ formate perovskites and highlight the important role of hydrogen bonding and dynamics.

Received 18th March 2016 Accepted 11th April 2016

DOI: $10.1039 / \mathrm{c} 6 \mathrm{sc} 01247 \mathrm{~g}$

www.rsc.org/chemicalscience respectively. ${ }^{\mathbf{1 2 - 1 4}}$ In general, hybrid perovskites show strong structural similarities to their inorganic counterparts ${ }^{\mathbf{1 5}}$ and well-established solid state principles were successfully applied to this emerging family. ${ }^{\mathbf{1 6}}$ In particular, the large variation due to $\mathrm{A}, \mathrm{B}$ or $\mathrm{X}$ site substitution permits the manipulation of bandgaps, ${ }^{17}$ dielectric responses, ${ }^{18}$ magnetic properties ${ }^{19}$ and so on. However, the chemical bond complexity in hybrid frameworks makes crystal engineering a challenging task, which, at the same time, can be seen as an opportunity to create frameworks with new and combined functionalities. balance (Fig. 1a). The hybrid perovskites $\left[\mathrm{CH}_{3} \mathrm{NH}_{3}\right] \mathrm{PbI}_{3}$ and $\left[\mathrm{NH}_{2} \mathrm{CHNH}_{2}\right] \mathrm{PbI}_{3},{ }^{9,10}$ which started a new paradigm in the area of thin film solar cells, are intriguing examples. ${ }^{11}$ Other examples include formate, azide and cyanide-based frameworks with the general formulas $\mathrm{AB}(\mathrm{HCOO})_{3}, \mathrm{AB}\left(\mathrm{N}_{3}\right)_{3}$ and $\mathrm{AB}(\mathrm{CN})_{3}$,

${ }^{a}$ Department of Materials Science and Metallurgy, University of Cambridge, 27 Charles Babbage Road, Cambridge CB3 OFS, UK

${ }^{b}$ Department of Chemistry, Graduate School of Science, Tohoku University, 6-3 AzaAoba, Aramaki, Aoba-ku, Sendai 980-8578, Japan

${ }^{c}$ WPI-Advanced Institute for Materials Research, Tohoku University, 2-1-1 Katahira, Aoba-ku, Sendai 980-8577, Japan

${ }^{d}$ Department of Chemistry, University of Cambridge, Lensfield Road, Cambridge CB2 $1 E W, U K$

${ }^{e}$ Lehrstuhl für Anorganische Chemie II, Ruhr-Universität Bochum, Germany

$\dagger$ Electronic supplementary information (ESI) available: Experimental details, description of crystal structure refinement and PXRD analysis, ${ }^{1} \mathrm{H}$ 2D BABA data and field dependent $60 \mathrm{kHz}{ }^{1} \mathrm{H}$ MAS NMR data. CCDC 1469426 and 1469427. For ESI and crystallographic data in CIF or other electronic format see DOI: $10.1039 / \mathrm{c} 6 \mathrm{sc} 01247 \mathrm{~g}$

\$ Authors contributed equally.
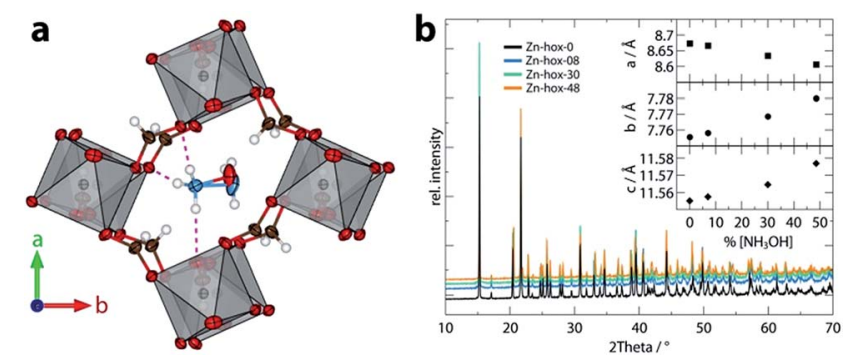

Fig. 1 View along the $c$ axis of the pseudocubic unit cell of $\mathrm{Zn}$-hox-48 (a) with emphasis on the hydrogen bonds (purple) of the $\mathrm{NH}_{3}{ }^{+}$-group and the different positions of the atoms $\mathrm{O} 7$ and N2 in the structure. In (b), the room temperature powder $\mathrm{X}$-ray diffraction pattern of the compounds $\left[\mathrm{NH}_{3} \mathrm{NH}_{2}\right]_{1-x}\left[\mathrm{NH}_{3} \mathrm{OH}\right]_{x} \mathrm{Zn}(\mathrm{HCOO})_{3}$ with $x=0$ (black), 0.08 (blue), 0.30 (green) and 0.48 (orange) are shown. The inset gives the evolution of lattice parameters along the solid solution. The lattice parameters were obtained from Pawley fits and fulfil Vegard's law. For Pawley fits and statistics, see ESI-Table 1 and ESI-Fig. $1 . \dagger$ 
Out of the many reported hybrid perovskites, formate-based materials show a notable large diversity and many different compounds with varying A-cations and metal species have been reported. ${ }^{12,20-22}$ Heterometallic hybrid formates are also known, e.g. $\left[\left(\mathrm{CH}_{3}\right)_{2} \mathrm{NH}_{2}\right] \mathrm{Na}_{0.5} \mathrm{Cr}_{0.5}(\mathrm{HCOO})_{3}$ and $\left[\mathrm{C}_{2} \mathrm{H}_{5} \mathrm{NH}_{3}\right] \mathrm{Na}_{0.5} \mathrm{Fe}_{0.5}$ $(\mathrm{HCOO})_{3},{ }^{23,24}$ which underline the compositional adaptability.

In all these compounds, the electronic configuration of the metal determines the low-temperature magnetic properties whereas the choice of the A cation, in particular the size, symmetry and molecular shape, is responsible for possible ferroelectric-to-paraelectric phase transitions. For instance, in $\left[\mathrm{NH}_{3} \mathrm{NH}_{2}\right] \mathrm{Zn}(\mathrm{HCOO})_{3}$, the ferroelectric-to-paraelectric phasetransition at $352 \mathrm{~K}$ is related to a temperature activated disorder of the $\mathrm{NH}_{2}$-group between two positions. Interestingly, magnetoelectric coupling was observed in $\left[\left(\mathrm{CH}_{3}\right)_{2} \mathrm{NH}_{2}\right] \mathrm{Fe}(\mathrm{HCOO})_{3}$, though the detailed nature of this phenomenon is still under debate. $^{25,26}$

Our work follows on from the important findings of Gao and co-workers who successfully prepared a solid solution between the two perovskite phases $\left[\mathrm{NH}_{3} \mathrm{NH}_{2}\right] \mathrm{Mn}(\mathrm{HCOO})_{3}$ and $\left[\mathrm{CH}_{3} \mathrm{NH}_{3}\right]$ $\mathrm{Mn}(\mathrm{HCOO})_{3}{ }^{18}$ Here, we describe the synthesis of the solidsolutions $\left[\mathrm{NH}_{3} \mathrm{NH}_{2}\right]_{1-x}\left[\mathrm{NH}_{3} \mathrm{OH}\right]_{x} \mathrm{Zn}(\mathrm{HCOO})_{3}$ with $x=0,0.08$, 0.30 and 0.48 , where the end-members crystallise in a perovskite-framework $\left(x=0,\left[\mathrm{NH}_{3} \mathrm{NH}_{2}\right] \mathrm{Zn}(\mathrm{HCOO})_{3}\right)$ and a chiral channel structure $\left(x=1,\left[\mathrm{NH}_{3} \mathrm{OH}\right] \mathrm{Zn}(\mathrm{HCOO})_{3}\right)$, respectively. ${ }^{27-29}$ Structural changes upon substitution are followed using powder and single crystal X-ray diffraction (PXRD and SCXRD) and differential scanning calorimetry (DSC), while ${ }^{1} \mathrm{H}$ magic angle spinning nuclear magnetic resonance spectroscopy $\left({ }^{1} \mathrm{H}\right.$ MAS NMR) is used to access the dynamics of the A-cation. The changes in crystal chemistry and its impact on mechanical responses are then probed using nanoindentation.

\section{Results and discussion}

\section{Synthesis and stoichiometry}

Mild solution synthesis was used for the preparation of all compounds in this work. Starting from $\mathrm{NH}_{2} \mathrm{NH}_{2} \cdot \mathrm{H}_{2} \mathrm{O} / \mathrm{NH}_{2}$ $\mathrm{OH} \cdot \mathrm{H}_{2} \mathrm{O}$ or $\mathrm{NH}_{2} \mathrm{NH}_{3} \mathrm{Cl} / \mathrm{HONH}_{3} \mathrm{Cl}, \mathrm{HCOOH}$ and $\mathrm{Zn}\left(\mathrm{ClO}_{4}\right)_{2}$. $6 \mathrm{H}_{2} \mathrm{O}$ in methanol, large crystals with sizes $>0.2 \mathrm{~mm}$ are easily accessible (ESI $\dagger$ ). Chemical analysis was then used to determine the chemical compositions of the products (Table 1). The lattice parameters obtained from PXRD data analysis (Fig. 1b) confirm that the solid-solutions obey Vegard's law. The lattice parameter

Table 1 Overview of $\left[\mathrm{NH}_{3} \mathrm{NH}_{2}\right]_{1-x}\left[\mathrm{NH}_{3} \mathrm{OH}\right]_{x} \mathrm{Zn}(\mathrm{HCOO})_{3}$ samples characterised in this work. The stoichiometry used during synthesis and real composition obtained from chemical analysis are given

$x$ in $\left[\mathrm{NH}_{3} \mathrm{NH}_{2}\right]_{1-x}\left[\mathrm{NH}_{3} \mathrm{OH}\right]_{x} \mathrm{Zn}(\mathrm{HCOO})_{3}$

Name

(Synthesis)

(Chemical analysis)

Zn-hox-0

Zn-hox-08

Zn-hox-30

Zn-hox-48
0

0.30

0.70

0.80

\section{0}

0.08

0.30

0.48 $a$ decreases along the series $(-0.72 \%)$, whereas the lattice parameters $b(+0.31 \%)$ and $c(+0.19 \%)$ increase, leading to only a slight decrease of the volume from $777.30 \AA^{3}$ to $775.16 \AA^{3}$. The subtle change in lattice parameters is consistent with the similar sizes of $\left[\mathrm{NH}_{3} \mathrm{NH}_{2}\right]^{+}, r_{\text {eff }}=217 \mathrm{pm}$ and $\left[\mathrm{NH}_{3} \mathrm{OH}\right]^{+} r_{\text {eff }}=$ $216 \mathrm{pm}^{16}$

\section{Crystal chemistry and dynamics}

In order to get further insights into the changes of crystal chemistry upon substitution, SCXRD of Zn-hox-48 $\left(\left[\mathrm{NH}_{3}-\right.\right.$ $\left.\left.\mathrm{NH}_{2}\right]_{0.52}\left[\mathrm{NH}_{3} \mathrm{OH}\right]_{0.48} \mathrm{Zn}(\mathrm{HCOO})_{3}\right)$ and Zn-hox-0 $\left(\left[\mathrm{NH}_{3} \mathrm{NH}_{2}\right]\right.$ $\left.\mathrm{Zn}(\mathrm{HCOO})_{3}\right)$ at $120 \mathrm{~K}$ was performed. Similar to the parent compound Zn-hox-0 (Pna2 $1, a=8.6706(2) \AA, b=7.72008(19) \AA$ and $c=11.4872(3) \AA$ ), structure solution of $\mathbf{Z n - h o x}-48$ was performed in the polar space-group $P n a 2_{1}$ with lattice parameters, $a=8.61779(12) \AA, b=7.73073(10) \AA$ and $c=11.50052(16) \AA$. The lattice parameters of Zn-hox-0 and Zn-hox-48 from SCXRD are consistent with the results from PXRD. In the electron density map, the oxygen atom of $\left[\mathrm{NH}_{3} \mathrm{OH}\right]^{+}$could be clearly identified and was refined to an occupancy of 0.50 , which is in good agreement with the results from chemical analysis. For the refinement, the total occupancy of the $\mathrm{OH}$-group of $\left[\mathrm{NH}_{3} \mathrm{OH}\right]^{+}$ and the $\mathrm{NH}_{2}$-group of $\left[\mathrm{NH}_{3} \mathrm{NH}_{2}\right]^{+}$was set to 1 , while the occupancies of both groups were refined freely. Detailed information about atomic positions and statistics of structure solution for Zn-hox-0 and Zn-hox-48 are given in ESI-Table 2-4. $\dagger$ In the final structural model for $\mathbf{Z n - h o x - 4 8}$, the position of the $\left[\mathrm{NH}_{3} \mathrm{NH}_{2}\right]^{+}$is effectively not changed in comparison to Zn-hox-0, leading to similar amine-cavity interactions. ${ }^{30}$ The oxygen atom of $\left[\mathrm{NH}_{3} \mathrm{OH}\right]^{+}$is slightly displaced with respect to the $\mathrm{NH}_{2}$-group of $\left[\mathrm{NH}_{3} \mathrm{NH}_{2}\right]^{+}$. This displacement is related to the loss of one hydrogen bond (HB) and the subsequent maximisation of the remaining $\mathrm{HB}$ strength between the $\mathrm{OH}$-group and the metalformate cavity; $d(\mathrm{O}-\mathrm{H} \cdots \mathrm{O})=2.769(15) \AA$ in comparison to the shortest $\mathrm{N}-\mathrm{H} \cdots \mathrm{O}$ distance in Zn-hox-0 $d(\mathrm{~N}-\mathrm{H} \cdots \mathrm{O})=2.998(2) \AA$. Additionally, a repulsion effect between the free lone pair at the oxygen atom and the negatively charged metal-formate cavity is possible and can support this displacement. Thus, the subtle shift of the $\left[\mathrm{NH}_{3} \mathrm{OH}\right]^{+}$axis with respect to the $\left[\mathrm{NH}_{3} \mathrm{NH}_{2}\right]^{+}$axis is a consequence of optimising the remaining amine-cavity interactions to increase the stability of the structure. Since the end members of the phase diagram crystallise in two different crystal structures, going along the solid solution $\left[\mathrm{NH}_{3} \mathrm{NH}_{2}\right]_{1-x}\left[\mathrm{NH}_{3} \mathrm{OH}\right]_{x} \mathrm{Zn}(\mathrm{HCOO})_{3}$ there is no driving force present that represents a transition from one distorted perovskite architecture to another. This is consistent with the small changes of trans $\mathrm{Zn}-\mathrm{Zn}-\mathrm{Zn}$ angles along $c$ of $170.04^{\circ} / 169.79^{\circ}$ and average $\mathrm{Zn}-\mathrm{O}$ distances of $d(\mathrm{Zn}-\mathrm{O})=2.103 / 2.104 \AA$ for $\mathbf{Z n}$ hox-0/Zn-hox-48, respectively.

The impact of substitution on the ferroelectric-to-paraelectric phase transition was analysed using DSC. With increasing $x$, the phase transition temperature $\left(T_{\mathrm{c}}\right)$ decreases linearly from $T_{\mathrm{c}}=352 \mathrm{~K}$ for $\mathbf{Z n}$-hox-0 to $T_{\mathrm{c}}=324 \mathrm{~K}$ for $\mathbf{Z n}-\mathbf{h o x}-\mathbf{4 8}$ (Fig. 2). For $\mathbf{Z n - h o x - 0 , ~ t h e ~ m o t i o n ~ o f ~ t h e ~} \mathrm{NH}_{2}$-group is hindered by HBs formed between the $\mathrm{NH}_{2}$-group and the metal-formate cavity. Additionally, the free electron pair located at the $\mathrm{NH}_{2}$ - 

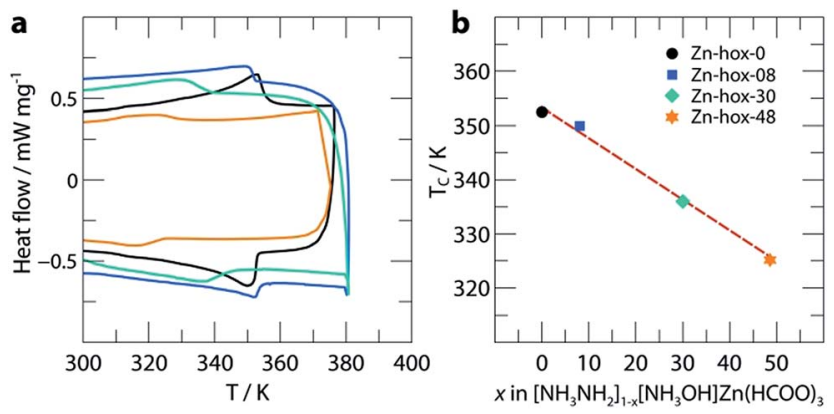

Fig. 2 DSC data (a) and phase transition temperatures (b) as a function of $x$ in $\left[\mathrm{NH}_{3} \mathrm{NH}_{2}\right]_{1-x}\left[\mathrm{NH}_{3} \mathrm{OH}\right]_{x} \mathrm{Zn}(\mathrm{HCOO})_{3}$. The dotted red line acts as a guide for the eye.

group points into free space to reduce electrostatic repulsion effects with the negatively charge metal-formate framework. The subtle distortion of the metal-cavity described above seems to perturb this balance and a motion of the $\mathrm{NH}_{2}$-group becomes more favourable than localised HBs. This is supported by the DSC signal, which flattens out and becomes thermally dispersed with increasing $x$. A similar trend was found for the decomposition temperature $\left(T_{\mathrm{D}}\right)$, which decreases from $T_{\mathrm{D}}=$ 394.9 K to $T_{\mathrm{D}}=392.3 \mathrm{~K}$ for Zn-hox-0 and Zn-hox-48, respectively (ESI-Fig. $2 \dagger$ ).

To investigate the impact of $\left[\mathrm{NH}_{3} \mathrm{NH}_{2}\right]^{+}$substitution on the dynamics and $T_{\mathrm{c}}$ in more detail, Zn-hox-48 was analysed using ${ }^{1} \mathrm{H}$ solid state NMR. The spectrum shows similar resonances to that of $\mathbf{Z n}$-hox-0 arising from the $\mathrm{HCOO}^{-}\left(\delta^{1} \mathrm{H}=8.4 \mathrm{ppm}\right)$ and $\mathrm{NH}_{3} \mathrm{NH}_{2}$ groups $\left(\delta{ }^{1} \mathrm{H}=9.3 \mathrm{ppm}\right.$ for $\mathrm{NH}_{3}$ and $4.0 \mathrm{ppm}$ for $\left.\mathrm{NH}_{2}\right),{ }^{30}$ while an additional resonance is observed at $\delta{ }^{1} \mathrm{H}=10.4$ ppm (Fig. 3a). The assignments of the $\mathrm{NH}_{3} \mathrm{OH}$ groups were made on the basis of a 2D double-quantum NMR experiment (Fig. $3 \mathrm{~b}$ and ESI-Fig. 3 and $4 \uparrow$ for details). The measured peak intensity ratios of $2.6: 4.1: 6.0: 2.1,\left(\mathrm{NH}_{3} \mathrm{OH}: \mathrm{NH}_{3} \mathrm{NH}_{2}\right.$ \& $\mathrm{NH}_{3} \mathrm{OH}: \mathrm{HCOO}: \mathrm{NH}_{3} \mathrm{NH}_{2}$ ) are in good agreement with the
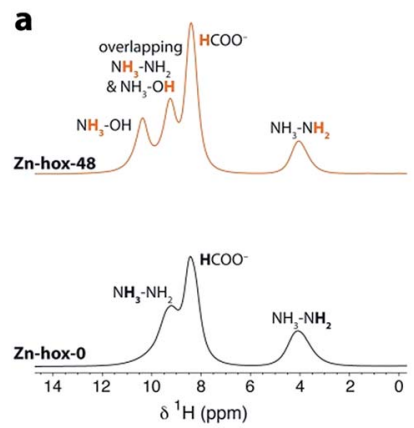

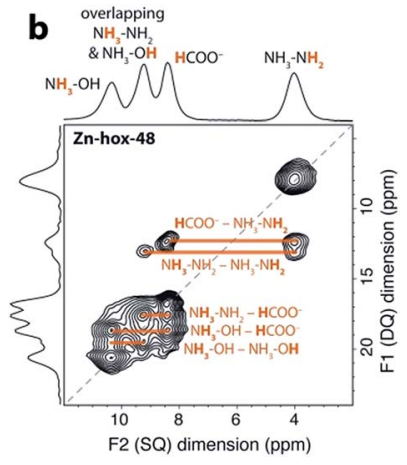

Fig. 3 (a) Experimental ${ }^{1} \mathrm{H}$ NMR (11.7 T) spectra of Zn-hox-0 and Znhox-48 are shown with an MAS frequency of $50 \mathrm{kHz}$. The chemical shifts and integrated intensities for $\mathbf{Z n - h o x - 4 8}$ are given in the text. At $50 \mathrm{kHz}$ MAS the average sample temperature is $\sim 307 \mathrm{~K}$, as determined from calibration experiments on lead nitrate. ${ }^{31}$ (b) ${ }^{1} \mathrm{H} 2 \mathrm{D}$ doublequantum spectrum (11.7 T) of $\mathrm{Zn}$-hox-48 at a MAS rate of $60 \mathrm{kHz}$. Orange lines show the different correlations and indicate hydrogen atoms that are close in space. expected ones for $x=0.48(2.9: 4.1: 6.0: 2.1)$, confirming the stoichiometry obtained by chemical analysis. Closer inspection of the NMR spectra in Fig. 3a shows that the peak linewidths are narrower for the Zn-hox-48 compound than the Zn-hox-0 compound. For example, the full-linewidth at half-maximum intensity (FWHM) of the hydrazinium $-\mathrm{NH}_{2}$ peak decreases from 1.07 ppm in Zn-hox-0 to 0.80 ppm in Zn-hox-48. Experiments at different magnetic field strengths and different MAS speeds (see ESI-Fig. $4 \dagger$ ) confirm that the peak linewidths are dominated by dipolar interactions between the spins. In this regime, motion of the hydrogen containing groups averages the ${ }^{1} \mathrm{H}$ dipolar interactions, with faster motion giving rise to narrower NMR peaks. ${ }^{32}$ We can therefore conclude that the hydrazinium cations are more mobile in $\mathbf{Z n - h o x}-\mathbf{4 8}$ than in $\mathbf{Z n -}$ hox-0. This observation is consistent with results from DSC analysis and the above mentioned decrease of $T_{\mathrm{c}}$. Hence, the introduction of hydroxylammonium cations in the $\mathrm{ReO}_{3}$-like cavities has an influence on the dynamics of hydrazinium cations located in other cavities. This finding points to the presence of cooperative effects mediated through the 3D metalformate framework, even though X-ray diffraction revealed only minor changes in the metal-formate cavity upon substitution. A similar mechanism, where the metal-formate cavity plays a key role, is currently discussed for magnetoelectric and magnetoelastic coupling pathways. ${ }^{25}$

\section{Mechanical properties}

Nanoindentation was used to study the mechanical properties for all compounds in this work, see ESI $\dagger$ for experimental details. Mechanical responses were measured at ambient temperatures along [110], which corresponds to the [100] direction of the pseudocubic perovskite unit cell (Fig. 1a). Along the solid solution, a significant decrease of the elastic moduli from $E_{110}=24.6 \mathrm{GPa}$ for Zn-hox-0 to $E_{110}=19.0 \mathrm{GPa}$ for Zn-hox48 is observed (Fig. 4a). Similarly, the hardness decreases from $H_{110}=1.25 \mathrm{GPa}$ for $\mathbf{Z n - h o x - 0}$ to $H_{110}=0.97 \mathrm{GPa}$ for $\mathbf{Z n}$-hox-48 (Fig. 4b). For more detailed results from nanoindentation, see ESI-Table $5 \dagger$ and ref. 30. The change of approx. 25\% for $E$ and $H$ can be linked to the chemical manipulation of amine-cavity
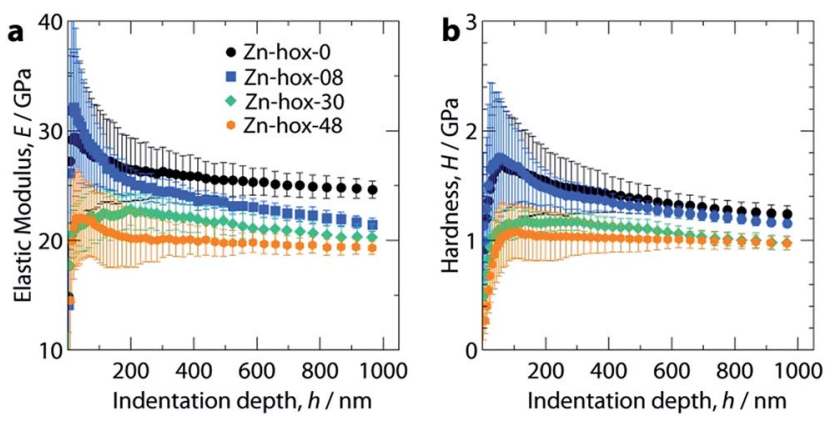

Fig. 4 Elastic moduli, $E$ (a) and hardness, $H$ (b) as a function of indentation depth, $h$ along [110]. With increasing $x$ in $\left[\mathrm{NH}_{3} \mathrm{NH}_{2}\right]_{1-x^{-}}$ $\left[\mathrm{NH}_{3} \mathrm{OH}\right]_{x} \mathrm{Zn}(\mathrm{HCOO})_{3}$, the elastic modulus and hardness decrease monotonically due to reduced hydrogen bonding interactions upon substitution. 
interactions across the series. The dependency of $E$ and $H$ with $x$ seems to be linear to a good approximation, which is consistent with PXRD, DSC and TGA data (ESI-Fig. 4 †).

In a previous study we have shown that amine-cavity interactions in Zn-hox-0 are relatively strong and we identified salt bridge-like interactions between the metal-formate cavity and the $\mathrm{NH}_{3}$-group, as well as two hydrogen bonds, medium in strength, formed by the $\mathrm{NH}_{2}$-group of $\left[\mathrm{NH}_{3} \mathrm{NH}_{2}\right]^{+}{ }^{30}$ By gradually replacing $\left[\mathrm{NH}_{3} \mathrm{NH}_{2}\right]^{+}$by $\left[\mathrm{NH}_{3} \mathrm{OH}\right]^{+}$, the number of HBs from the A cation to the metal-formate cavity is effectively reduced. This can be seen as a first order effect which is responsible for a relatively large decrease in the mechanical stability of the framework. The displacement of the $\left[\mathrm{NH}_{3} \mathrm{OH}\right]^{+}$discussed above, together with the more polarized $\mathrm{O}-\mathrm{H}$ bond, strengthen the newly formed $\mathrm{HB}$ between the $\mathrm{OH}$-group and the cavity. This partially compensates for the weakening of the framework caused by the first order effect. Additionally, the more polar $\mathrm{N}-\mathrm{O}$ bond in $\left[\mathrm{NH}_{3} \mathrm{OH}\right]^{+}$and the subsequent strengthening of amine-cavity interactions of the $\mathrm{NH}_{3}$-group can play a role. Thus, the change in mechanical properties can be linked to the replacement of $\left[\mathrm{NH}_{3} \mathrm{NH}_{2}\right]^{+}$with $\left[\mathrm{NH}_{3} \mathrm{OH}\right]^{+}$, which has a complex influence on the crystal chemistry of the compound.

\section{Conclusion}

In conclusion, we have shown how the dynamics, phase transition temperatures and mechanical properties can be tuned in formate perovskites by using the solid-solution approach. Within the series $\left[\mathrm{NH}_{3} \mathrm{NH}_{2}\right]_{1-x}\left[\mathrm{NH}_{3} \mathrm{OH}\right]_{x} \mathrm{Zn}(\mathrm{HCOO})_{3}(x=0,0.08,0.30$ and 0.48), the progressive substitution of $\left[\mathrm{NH}_{3} \mathrm{NH}_{2}\right]^{+}$by $\left[\mathrm{NH}_{3} \mathrm{OH}\right]^{+}$ induces a subtle but complex change in crystal chemistry. The variation of one structural parameter, i.e. the removal of HBs, induces a cascade of small distortions which then significantly influence the properties of the compounds. ${ }^{1} \mathrm{H}$ solid state NMR indicates higher mobility of $\left[\mathrm{NH}_{3} \mathrm{NH}_{2}\right]^{+}$in $\mathbf{Z n}$-hox-48 with respect to Zn-hox-0. Consequently, the ferroelectric-to-paraelectric phase transition temperature decreases from $T_{\mathrm{c}}=352 \mathrm{~K}$ for Zn-hox-0 to $T_{\mathrm{c}}=324 \mathrm{~K}$ for $\mathbf{Z n}-\mathbf{h o x}-\mathbf{4 8}$, because the threshold temperature where the entropy gain overcomes the loss in enthalpy decreases. A more direct effect of the loss of HBs upon substitution is the increased compliance of the framework. This is reflected in the elastic moduli and hardnesses of the systems which decrease from $E_{110}=24.6 \mathrm{GPa}$ and $H_{110}=1.25 \mathrm{GPa}$ for $\mathbf{Z n}$-hox-0 to $E_{110}=$ $19.0 \mathrm{Gpa}$ and $H_{110}=0.97 \mathrm{GPa}$ for Zn-hox-48. This confirms previous results in which the sensitivity of mechanical properties towards amine-cavity interactions was demonstrated. ${ }^{33}$ The variation of A-cation dynamics, however, is complex and underlines the challenges materials scientists face when preparing new materials with targeted functionalities. The results presented here are consistent with the solid solution $\left[\mathrm{NH}_{3} \mathrm{NH}_{2}\right]_{1-x}\left[\mathrm{CH}_{3}-\right.$ $\left.\mathrm{NH}_{3}\right]_{x} \mathrm{Mn}(\mathrm{HCOO})_{3}$ reported by Gao and co-workers. ${ }^{18}$ We have gone beyond their work by studying the A cation dynamics by ${ }^{1} \mathrm{H}$ NMR and the mechanical properties using nanoindentation. Additionally, by using a protonated amine as a substituent that does not form a perovskite structure in its pure form, our work opens a new dimension in tuning properties of formate perovskite frameworks.

\section{Acknowledgements}

GK is the holder of a postdoctoral fellowship granted by the Deutsche Forschungsgemeinschaft (KI1870). GK and AKC gratefully thank the Ras Al Khaimah Center for Advanced Materials for financial support. SH thanks the Alexander von Humboldt Foundation for financial support. SS is supported by the Cambridge Overseas Trust and China Scholarship Council. ACF acknowledges the Sims Scholarship for funding.

\section{References}

1 A. K. Cheetham and C. N. R. Rao, Science, 2007, 318, 58-59. 2 W. Zhang and R.-G. Xiong, Chem. Rev., 2012, 112, 1163-1195.

3 P. Jain, V. Ramachandran, R. J. Clark, H. D. Zhou, B. H. Toby, N. S. Dalal, H. W. Kroto and A. K. Cheetham, J. Am. Chem. Soc., 2009, 131, 13625-13627.

4 W. Li, Z. Zhang, E. G. Bithell, A. S. Batsanov, P. T. Barton, P. J. Saines, P. Jain, C. J. Howard, M. A. Carpenter and A. K. Cheetham, Acta Mater., 2013, 61, 4928-4938.

5 Z. Wang, B. Zhang, T. Otsuka, K. Inoue, H. Kobayashi and M. Kurmoo, Dalton Trans., 2004, 2209-2216.

6 P. J. Saines, P. T. Barton, M. Jura, K. S. Knight and A. K. Cheetham, Mater. Horiz., 2014, 1, 332-337.

7 T. Besara, P. Jain, N. S. Dalal, P. L. Kuhns, A. P. Reyes, H. W. Kroto and A. K. Cheetham, Proc. Natl. Acad. Sci. U. S. A., 2011, 108, 6828-6832.

8 M. Mączka, A. Ciupa, A. Gągor, A. Sieradzki, A. Pikul, B. Macalik and M. Drozd, Inorg. Chem., 2014, 53, 5260-5268.

9 D. Weber, Z. Naturforsch., 1978, 33b, 1443-1445.

10 M. Liu, M. B. Johnston and H. J. Snaith, Nature, 2013, 501, 395-398.

11 M. A. Green and T. Bein, Nat. Mater., 2015, 14, 559-561.

12 Z. Wang, K. Hu, S. Gao and H. Kobayashi, Adv. Mater., 2010, 22, 1526-1533.

13 X.-H. Zhao, X.-C. Huang, S.-L. Zhang, D. Shao, H.-Y. Wei and X.-Y. Wang, J. Am. Chem. Soc., 2013, 135, 16006-16009.

14 W. Zhang, Y. Cai, R.-G. Xiong, H. Yoshikawa and K. Awaga, Angew. Chem., Int. Ed., 2010, 49, 6608-6610.

15 G. Kieslich, S. Sun and A. K. Cheetham, Chem. Sci., 2015, 6, 3430-3433.

16 G. Kieslich, S. Sun and A. K. Cheetham, Chem. Sci., 2014, 5, 4712-4715.

17 E. T. Hoke, D. J. Slotcavage, E. R. Dohner, A. R. Bowring, H. I. Karunadasa and M. D. McGehee, Chem. Sci., 2015, 6, 613-617.

18 S. Chen, R. Shang, B.-W. Wang, Z.-M. Wang and S. Gao, Angew. Chem., Int. Ed., 2015, 54, 11093-11096.

19 R. Shang, X. Sun, Z.-M. Wang and S. Gao, Chem.-Asian J., 2012, 7, 1697-1707.

20 S. M. Bovill and P. J. Saines, CrystEngComm., 2015, 17, 83198326.

21 B. Pato-Doldán, L. C. Gómez-Aguirre, J. M. Bermúdez-García, M. Sánchez-Andújar, A. Fondado, J. Mira, S. Castro-García and M. A. Señarís-Rodríguez, RSC Adv., 2013, 3, 22404.

22 L. C. Gómez-Aguirre, B. Pato-Doldán, A. Stroppa, S. YáñezVilar, L. Bayarjargal, B. Winkler, S. Castro-García, J. Mira, 
M. Sánchez-Andújar and M. A. Señarís-Rodríguez, Inorg. Chem., 2015, 54, 2109-2116.

23 M. Mączka, B. Bondzior, P. Dereń, A. Sieradzki, J. Trzmiel, A. Pietraszko and J. Hanuza, Dalton Trans., 2015, 44, 68716879.

24 M. Ptak, M. Mączka, A. Gągor, A. Sieradzki, A. Stroppa, D. Di Sante, J. M. Perez-Mato and L. Macalik, Dalton Trans., 2016, 45, 2574-2583.

25 W. Wang, L.-Q. Yan, J.-Z. Cong, Y.-L. Zhao, F. Wang, S.-P. Shen, T. Zou, D. Zhang, S.-G. Wang, X.-F. Han and Y. Sun, Sci. Rep., 2013, 3, 2024.

26 N. Abhyankar, S. Bertaina and N. S. Dalal, J. Phys. Chem. C, 2015, 119, 28143-28147.

27 S. Chen, R. Shang, K.-L. Hu, Z.-M. Wang and S. Gao, Inorg. Chem. Front., 2014, 1, 83-98.
28 B. Liu, R. Shang, K.-L. Hu, Z.-M. Wang and S. Gao, Inorg. Chem., 2012, 51, 13363-13372.

29 G. Kieslich, S. Kumagai, K. T. Butler, T. Okamura, C. H. Hendon, S. Sun, M. Yamashita, A. Walsh and A. K. Cheetham, Chem. Commun., 2015, 51, 15538-15541.

30 G. Kieslich, A. C. Forse, S. Sun, K. T. Butler, S. Kumagai, Y. Wu, M. R. Warren, A. Walsh, C. P. Grey and A. K. Cheetham, Chem. Mater., 2016, 28, 312-317.

31 P. A. Beckmann and C. Dybowski, J. Magn. Reson., 2000, 146, 379-380.

32 S. P. Brown, Solid State Nucl. Magn. Reson., 2012, 41, 1-27. 33 W. Li, A. Thirumurugan, P. T. Barton, Z. Lin, S. Henke, H. H. M. Yeung, M. T. Wharmby, E. G. Bithell, C. J. Howard and A. K. Cheetham, J. Am. Chem. Soc., 2014, 136, 7801-7804. 